\title{
The European Higher Education Area: A road to the future or at way's end?
}

\author{
Sjur Bergan* \\ doi: http://dx.doi.org/10.18543/tjhe-6(2)-2019pp23-49
}

Received: 08-04-2019

Accepted: 29-04-2019

\begin{abstract}
The goal of the Bologna Process was to develop a European Higher Education Area within a decade. The goal and the process proved to be attractive, new countries steadily applied for accession, and the Bologna Process has brought about substantial reforms. At the same time, the drive and optimism of the early years has given way to more measured optimism and even a sense of disillusion as we approach the 20th anniversary of the Bologna Declaration. The article outlines six phases in the development of the European Higher Education Area and then looks at some of the main challenges the EHEA faces as it approaches its third decade. Structural reforms have been the hallmark of the EHEA, and in this area the main challenges concern implementation rather than the development of new structures even if some policy challenges also remain. In the run-up to the 2018 Ministerial conference, EHEA faced a bitter debate on the character of the EHEA itself, linked to the questions of how to foster implementation of commitments undertaken and what it means to be a voluntary process. The fundamental values on which the EHEA builds are now threatened in some EHEA members, the role of the EHEA in a global context, and its relevance and governance constitute other challenges.
\end{abstract}

Keywords: Bologna Process; European Higher Education Area; structural reforms; fundamental values; higher education cooperation; higher education governance; higher education policy; intergovernmental cooperation.

* Sjur Bergan (sjur.bergan@coe.int) is Head of the Education Department of the Council of Europe and leads the current Council of Europe projects on Competences for Democratic Culture and the European Qualifications Passport for Refugees.

More information about the author is available at the end of the article. 


\section{Introduction}

The march toward a European Higher Education Area (EHEA) was launched by Ministers of 29 European countries in Bologna in June 1999. The goal of the Bologna Process was to develop a European Higher Education Area within a decade, ${ }^{1}$ normally interpreted as meaning by 2010 . This was an ambitious goal, even if it may have been lacking in more specific goals and milestones.

If I were to venture a brief and unofficial description of the goals of the EHEA at the outset, it would be to create a higher education area in which students could move freely without losing any part of the value of their qualifications in the process. Structural reforms were seen as the main tools to make this vision come true. Today, the EHEA web site describes the Area as:

a unique international collaboration on higher education and the result of the political will of 48 countries with different political, cultural and academic traditions, which, step by step during the last twenty years, built an area implementing a common set of commitments: structural reforms and shared tools. These 48 countries agree to and adopt reforms on higher education on the basis of common key values, such as freedom of expression, autonomy for institutions, independent student unions, academic freedom, free movement of students and staff. Through this process, countries, institutions and stakeholders of the European area continuously adapt their higher education systems making them more compatible and strengthening their quality assurance mechanisms. For all these countries, the main goal is to increase staff and students' mobility and to facilitate employability.

The goal and the process proved to be attractive, and new countries steadily applied for accession. The Bologna Process fulfilled the ideal of the classical French tragedies: the preferred option is to be loved but it is better to be hated than to be ignored. Ignored the Bologna Process was not in its first decade, and it was loved much more than it was hated.

It was one of the strengths of the movement toward a European Higher Education Area that Ministers early on understood the goals could not be reached unless the Process were overseen by a structure where member states were represented at civil service level ${ }^{3}$ and that would meet in between

${ }^{1}$ Bologna Process, "The Bologna Declaration of 19 June 1999. Joint declaration of the European Ministers of Education," accessed April 8, 2019, http://www.ehea.info/Upload/ document/ministerial_declarations/1999_Bologna_Declaration_English_553028.pdf.

2 "European Higher Education Area and Bologna Process," accessed April 29, 2019, http://www.ehea.info/.

${ }^{3}$ The Bologna Follow Up Group (BFUG) is made up of representatives of the Ministry responsible for higher education of every EHEA member state. In addition, the European 
Ministerial meetings that came to form a series of milestones. Therefore, Ministers met every two - three years ${ }^{4}$ and the Bologna Follow Up Group (BFUG) twice a year. ${ }^{5}$

These were complemented by milestones of a different kind. As the Bologna Process approached its half way mark, those most closely involved came to understand that if a European Higher Education Area were to be established in 2010, progress toward that goal needed to be verified at regular intervals. This is the origin of what was first called the Bologna stocktaking and has since 2012 been the implementation report. ${ }^{6}$ We have come to take it for granted, but the fact that Ministers accepted that a loosely organized process would include a fairly independent assessment of the extent to which individual countries implement the commitments they undertake was a significant development and an issue that was to resurface more than 10 years later, in the run-up to the 2018 Ministerial conference in Paris.

The present article will seek to provide an overview of major developments in the Bologna Process so far and of some major challenges to the EHEA as it enters its third decade. The author does not lay claim to neutrality: continuous involvement with the BFUG and its Board over almost two decades, including three periods as Chair of the Working Group on Qualifications Frameworks and one period as Co-Chair of the Working Group on Structural Reforms would not make such a claim credible. However, I hope to have demonstrated at least a measure of ability to look at the EHEA with some critical distance through previous writings, in particular through contributions to two editions of the Bologna Process Researchers' Conference. ${ }^{7,8}$

Commission is a member, while the Council of Europe, UNESCO, and six stakeholder organizations (EUA, EURASHE, ESU, ENQA, Education International, Business Europe) are consultative members.

${ }^{4}$ Every two years in the period 1999 - 2009, followed by a conference in 2010 to mark the formal launch of the EHEA. Since then conferences were held in 2012, 2015, and 2018, and the next will be held in June 2020.

${ }^{5}$ Except in the year in which the Ministerial meeting is held, when the BFUG holds two meetings in the semester preceding the conference to finalize the draft communiqué.

6 An overview will be found at http://www.ehea.info/page-implementation, accessed on April 8, 2019.

7 Sjur Bergan, "The EHEA at the Cross-roads. The Bologna Process and the Future of Higher Education," in The European Higher Education Area: Between Critical Reflections and Future Policies, eds. Adrian Curaj, Liviu Matei, Remus Pricopie, Jamil Salmi and Peter Scott (Heidelberg: Springer Open Access, 2015), 737-752.

${ }^{8}$ Sjur Bergan and Ligia Deca, "Twenty Years of Bologna and a Decade of EHEA: What is Next?," in European Higher Education Area: the Impact of Past and Future Policies, eds. 


\section{Stages of development}

As argued elsewhere, ${ }^{9}$ the EHEA has developed through several stages, the timing of which can best be indicated with reference to the Ministerial conferences.

The first phase (Bologna 1999, ${ }^{10}$ Praha $^{11}$ 2001, arguably also the Sorbonne conference of 1998) marks the launching of the Bologna Process. This was an exciting time because the discussion was entirely about goals for a future that seemed distant even if participants knew a decade is short by any historical standards and that deadlines have a way of arriving sooner than expected. There was a feeling of optimism, of being part of an important European movement, and of higher education policy moving from the periphery of political concerns to a place closer to the center.

The second phase (Berlin 2003, Bergen 2005) was one of dynamic development as well as of the beginning realization of the need for what was then called stocktaking. There was still an optimistic feeling of purpose and at the same time a sense that the Bologna Process was maturing and required more careful policy development. Important initiatives like the overarching framework of qualifications of the EHEA and the Standard and Guidelines for Quality Assurance in the European Higher Education Area (ESG) were launched in Berlin ${ }^{12}$ and adopted in Bergen. ${ }^{13}$ The need for

Curaj et al. (Heidelberg/Bucureşti: Springer Open/UEFISCDI , 2018), 283-306, Accessed April 8, 2019, https://link.springer.com/chapter/10.1007/978-3-319-77407-7_19.

9 Bergan, "The EHEA at the Cross-roads. The Bologna Process and the Future of Higher Education," 737-752.

${ }^{10}$ Each conference adopted a Declaration or a Communiqué provided in the list of references as "Bologna Process YEAR. TITLE". They are easily accessible through http:// www .ehea.info/page-ministerial-declarations-and-communiques, accessed on April 8, 2019.

${ }^{11}$ While English is the language of communication of the EHEA, the present author feels that using the original version of proper names, including of cities, constitutes a mark of respect and recognition of the multi-cultural and multilingual nature of the EHEA. An exception is made where the anglicized form is a part of the official name of a document, so the 2001 meeting was held in Praha but the document adopted by Ministers is referred to as the Prague Communiqué. Translating proper names betrays a double imperfection: the inability to cope with foreign names, and the limits of our geographical and other knowledge, since one can only "translate" names of cities one has heard about.

${ }_{12}$ Bologna Process, "Realising the European Higher Education Area" (Communiqué of the Conference of Ministers responsible for Higher Education, Berlin, 2003), accessed April 8, 2019, http://www.ehea.info/Upload/document/ministerial_declarations/2003_Berlin_ Communique_English_577284.pdf.

${ }_{13}$ Bologna Process, "The European Higher Education Area - Achieving the Goals" (Communique of the Conference of European Ministers Responsible for Higher Education, 
verifying progress was recognized by Ministers in Berlin and the first stocktaking report submitted to them in Bergen. The stocktaking reports were preceded by a series of Trends reports developed by the EUA ${ }^{14}$ - the first as a background document for the 1999 Bologna conference - as well as by ESU's Bologna with Student Eyes, published for the first time in 2003. ${ }^{15}$ This was also the time of the greatest expansion of the Bologna Process from the original 29 (or 30) ${ }^{16}$ countries to 40 in Berlin and 45 in Bergen.

The third phase (London 2007, Leuven/Louvain-la-Neuve 2009, Budapest and Wien 2010) was marked by consolidation. By the time Ministers met in London, more than half the decade lay behind them. The approaching deadline focused Ministers' minds on what they had committed to achieving in 10 years and dampened their enthusiasm for undertaking new commitments. The London conference adopted a new strategy for the relationship between the EHEA and other areas of the world ${ }^{17,18}$ and two further countries joined but there was a feeling of a process slowing down. To boot, one of the two new countries rejoined rather than joined, since Montenegro had been a part of the EHEA as part of Serbia and Montenegro until its declaration of independence in 2006. Kazakhstan's accession, which was not uncontested, was seen as marking the eastern limits of the EHEA. At the same time, this was a period of success as the 2010 conference marked the transition from a process to an area - from the Bologna Process to the European Higher Education Area. This was no small achievement.

The fourth phase (Bucureşti 2012) was the first phase of the established $\boldsymbol{E H E A}$. The EHEA had become a fact of life of European higher education

Bergen, May 19-20, 2005), accessed April 8, 2019, http://www.ehea.info/Upload/document/ ministerial_declarations/2005_Bergen_Communique_english_580520.pdf.

${ }^{14} \mathrm{https} / / /$ eua.eu/resources/publications.html?\&search=Trends\&filter_year=\&filter_ issue, accessed on April 29, 2019.

$15 \mathrm{http}: / /$ www .ehea.info/page-bologna-with-student-eyes.

${ }^{16}$ The Ministers of 29 countries signed the Bologna Declaration. In 2001 three further countries joined the Bologna process, bringing the total number of member countries to... 33 . The explanation was that Liechtenstein, while a member of the European Economic Area, was for some unknown reason not invited to sign the Bologna Declaration but was quietly added to the Bologna Process membership later.

17 Bologna Process, "London Communiqué. Towards the European Higher Education Area: responding to challenges in a globalised world" (Communiqué of the Conference of European Ministers Responsible for Higher Education, London, 2007), accessed April 8, 2019, http://www.ehea.info/Upload/document/ministerial_declarations/2007_London_ Communique_English_588697.pdf.

${ }^{18}$ Bologna Process, "European Higher Education in a Global Setting. A Strategy for the External Dimension of the Bologna Process," accessed April 8, 2019, https://media.ehea.info/ file/2007_London/35/4/2007_London_Strategy-for-EHEA-in-global-setting_581354.pdf. 
but no longer attracted the same political interest as before. At the Bucureşti conference 13 of the then 47 member states were represented by highranking civil servants rather than Ministers or Deputy Ministers. ${ }^{19}$ At the same time, Ministers were presented with substantial reports and proposals not only on structural reforms as well as on academic mobility, which were the original "Bologna topics", but also on the social dimension of higher education, student centered learning, and student support. Not least, the Romanian Bologna Secretariat that served the EHEA between 2010 and 2012 was, in my view, the best we have ever had. Most Secretariat members had their background from the European and Romanian student movement and brought commitment, organizational skills, and knowledge and understanding of education policy to the Process.

The fifth phase (Yerevan 2015) could be seen as part of the early EHEA and therefore as part of the fourth phase. I nevertheless prefer to see it as a separate phase marked by both concerns that the EHEA was stalling and renewed optimism in the run-up to and immediate aftermath of the Yerevan conference, helped by what was seen as a dynamic conference at which Ministers had greater influence over the final wording of the Communiqué than at previous conferences. The Yerevan conference welcomed Belarus as a member of the EHEA, accompanied by a Roadmap ${ }^{20}$ stipulating the reforms Belarus committed to undertaking by 2018 in view of the fact that it joined the EHEA five years after the Area was formally established and also in view of concerns that had prevented its application from being accepted in 2012 and that had dissuaded the country from applying in 2005. The Yerevan conference was also the half way mark in the second decade of the Bologna Process and the first decade of the EHEA.

By this measure, the 2018 Paris conference must be considered as marking a sixth phase. By the time Ministers gathered, they were closer to the start of a new decade of the EHEA than to the halfway mark of the current decade, which should have focused minds on the implementation of current goals and the definition of new ones. A more important argument for counting the Paris meeting as a sixth phase was the fact that the optimism felt in Yerevan had long since vanished through a series of particularly difficult discussions in the BFUG.

${ }^{19}$ Sjur Bergan and Ligia Deca, "Twenty Years of Bologna and a Decade of EHEA: What is Next?," 283-306.

${ }^{20}$ Bologna Process 2015 b, "Belarus Roadmap for Higher Education Reform". Accessed April 8, 2019. http://www.ehea.info/media.ehea.info/file/2015_Yerevan/70/9/Roadmap_ Belarus_21.05.2015_613709.pdf. 
The state of implementation was an important part of the focus but in a peculiar way. The discussions in the BFUG in the run up to the Paris meetings were more acrimonious than at any previous time, and the acrimony focused on the character of the process: should it be voluntary in the sense that joining was optional but once a country had joined, it would be expected to implement its commitments, or should it be voluntary in the sense that the policies and commitments undertaken through Ministerial declarations and communiqués should be considered as aspirations rather than as real commitments? There had been some discussion of the character of the EHEA previously, ${ }^{21,22}$ but it now resurfaced much more strongly and questioned some of the assumptions underlying the stocktaking and implementation reports. The end result was a compromise that emphasized peer learning on key commitments related to structural reforms overseen by a Bologna Implementation Coordination Group (BICG).$^{23}$

On the background of this brief overview of the development of the EHEA, it is now time to turn to a thematic consideration of some of the main challenges facing the EHEA as it turns twenty and as it prepares for the 2020 Ministerial conference.

\section{Structural reforms}

Structural reforms are in many ways the hallmark of the EHEA and its main success story.$^{24}$ The EHEA is certainly not a household name outside of the circles of those working in and on higher education. Nevertheless, the

${ }^{21}$ Sjur Bergan, "The EHEA at the Cross-roads. The Bologna Process and the Future of Higher Education," in The European Higher Education Area: Between Critical Reflections and Future Policies, eds. Adrian Curaj, Liviu Matei, Remus Pricopie, Jamil Salmi and Peter Scott (Heidelberg: Springer Open Access, 2015) 737 - 752.

${ }^{22}$ Robert Harmsen, "Future Scenarios for the European Higher Education Area: Exploring the Possibilities of "Experimentalist Governance"," in The European Higher Education Area: Between Critical Reflections and Future Policies, eds. Adrian Curaj, Liviu Matei, Remus Pricopie, Jamil Salmi and Peter Scott (Heidelberg: Springer Open Access, 2015) $785-803$

${ }^{23}$ Bologna Process, "Paris Communiqué" (Communiqué of the Conference of European Ministers Responsible for Higher Education, Paris, 2018), accessed April 8, 2019, http://www. ehea.info/Upload/document/ministerial_declarations/EHEAParis2018_Communique_ final_952771.pdf.

${ }^{24}$ Bologna Process, "Report by the Structural Reforms Working Group to the BFUG" (Strasbourg, Brussels, Vatican City, Warsaw, December 8, 2014), accessed April 8, 2019, http://www.ehea.info/media.ehea.info/file/2015_Yerevan/72/1/Final_Report_of_the_ Structural_Reforms_WG_613721.pdf. 
reform of the degree structure is better known, even if people do not always relate it of the EHEA. In France, for example, "LMD" - licence, mastère, doctorat; the French for "bachelor, master's, doctorate" - is a fairly well known term.

\section{III.1. Quality assurance}

The structural reforms of the EHEA focus on qualifications and quality assurance. The Standards and Guidelines for Quality Assurance in the European Higher Education Area (ESG) ${ }^{25}$ have become the gold standard for quality assurance in Europe and no country can afford to ignore them. Even when some actors express criticism of quality assurance, they tend to do so in relation to the ESG.

Two developments since the launch of the Bologna Process are worth noting. On the one hand, the need for quality assurance was accepted over a period of less than five years. In 1997, when the Lisbon Recognition Convention ${ }^{26}$ was adopted, there was still discussion of whether formal quality assurance was required. Therefore, Section VIII of the Convention, on provision of information on the institutions and programs making up the higher education system of the Parties, distinguishes between those countries that have a formal quality assurance system and those that do not. Only five years later, the discussion was no longer about whether quality assurance was needed but about what form it should take. Quality assurance was first mentioned explicitly in the Prague Communiqué, ${ }^{27}$ work on the ESG was launched through the Berlin Communiqué, ${ }^{28}$ and both were adopted through

${ }^{25}$ Bologna Process, "Standards and Guidelines for Quality Assurance in the European Higher Education Area (ESG)," revised version (Approved by the Ministerial Conference in May 2015), accessed April 8, 2019, http://www.ehea.info/media.ehea.info/file/2015_ Yerevan/72/7/European_Standards_and_Guidelines_for_Quality_Assurance_in_the_ EHEA_2015_MC_613727.pdf.

${ }^{26}$ Council of Europe and UNESCO, "Convention on the Recognition of Qualifications concerning Higher Education in the European Region" (Lisbon Recognition Convention 1997), accessed April 16, 2019, https://www.coe.int/en/web/conventions/full-list/-/ conventions/treaty/165.

${ }^{27}$ Bologna Process, "Towards the European Higher Education Area" (Communiqué of the meeting of European Ministers in charge of Higher Education, Prague, May 19, 2001), accessed April 8,2019,http://www.ehea.info/Upload/document/ministerial_declarations/2001_ Prague_Communique_English_553 442.pdf.

${ }^{28}$ Bologna Process, "Berlin Communiqué" (2003). 
the Bergen Communiqué; ${ }^{29}$ while the European Quality Assurance Register for higher education (EQAR) was established in 2008. The ESG were revised at the Yerevan conference, and the debate focused on the finer details of the revision rather than on major principles. ${ }^{30,31}$

The second noteworthy aspect of quality assurance is that while it is recognized as the sole responsibility of the public authorities responsible for the respective education systems and quality assurance agencies act on a mandate from those public authorities,$^{32}$ the agencies are located outside of the public authorities and cannot be instructed in detail, including in specific cases of institutional recognition. This causes some concern in countries with a strong tradition of the Ministry as the ultimate authority in all matters pertaining to higher education but is a core requirement for independent and credible quality assurance. The stakeholder organizations for higher education institutions (EUA, EURASHE), students (ESU), and the quality assurance agencies (ENQA) played a decisive role in the development of the ESG and the establishment of EQAR. The standards and guidelines, while considered by the BFUG and adopted by Ministers, was therefore developed by stakeholder organizations.

Quality assurance is probably the aspect of the EHEA policies and commitments where oversight is the strongest and the least contested. EQAR functions as a de facto monitoring body, the membership of which is conditioned on compliance with the ESG, and this compliance is assessed at regular intervals, as is also true for ENQA.

One substantial challenge is to make quality assurance international. Ministers have expressed the intention to make it possible for an institution to seek quality assurance from an agency outside of the country in which the institution operates,$^{33}$ but so far only 12 countries have fully accepted that

${ }^{29}$ Bologna Process, "Bergen Communiqué (2005).

30 Bologna Process, "Yerevan Communiqué" (Communiqué of the Conference of European Ministers Responsible for Higher Education, Yerevan, May 14-15, 2015), accessed April 8, 2019, http://www.ehea.info/media.ehea.info/file/2015_Yerevan/70/7/ YerevanCommuniqueFinal_613707.pdf

${ }^{31}$ Bologna Process, "European Standards and Guidelines for Quality Assurance in EHEA," revised version (2015).

${ }^{32}$ Council of Europe, "Recommendation Rec/CM(2007)6 by the Committee of Ministers to member states on the public responsibility for higher education and research," accessed April 8, 2019, https://search.coe.int/cm/Pages/result_details. aspx?ObjectId=09000016805d5dae.

${ }_{33}$ Bologna Process, "Making the Most of Our Potential: Consolidating the European Higher Education Area. Bucharest Communiqué" (Communiqué of the Conference of European Ministers Responsible for Higher Education, Bucharest, April 26 - 27, 2012), 
institutions belonging to their system can be quality assured by foreign agencies registered in EQAR, while another 12 countries have gone a considerable way in doing so. ${ }^{34}$

\section{III.2. Recognition}

Recognition is an older policy area than quality assurance and the key standard of the EHEA antedates the Bologna Process. The Lisbon Recognition Convention ${ }^{35}$ was developed by the Council of Europe and UNESCO, it was adopted in April 1997, and it replaced several older conventions, the oldest of which dated from the 1950s.

The recognition of qualifications has been a success in that all EHEA members but one (Greece) have now ratified ${ }^{36}$ the Lisbon Recognition Convention, which has become the "gold standard" for recognition in Europe in the same way as the ESG have for quality assurance. The Lisbon Recognition Convention also provides a link with the broader world of recognition as it has been ratified by a number of countries outside of the EHEA (Australia, Canada, Kyrgyzstan, New Zealand, and Tajikistan) and is linked to the UNESCO system of regional conventions. It will also be linked to the global UNESCO Convention that will most likely be submitted for adoption to the General Conference in October/November 2019.

The success in this policy area is more mixed if we look at the implementation of the Convention. ${ }^{37}$ The implementation of some parts of the Convention, such as the establishment and functioning of national information centers is broadly satisfactory, where the implementation of other parts - notably Article VII on the recognition of refugees' qualifications

accessed April 8, 2019, http://www.ehea.info/Upload/document/ministerial_declarations/ Bucharest_Communique_2012_610673.pdf.

${ }^{34}$ European Commission/EACEA/Eurydice, "The European Higher Education Area in 2018: Bologna Process Implementation Report" (Luxembourg: Publications Office of the European Union, 2018), 140, accessed April 8, 2019. http://www .ehea.info/Upload/BP2018. pdf.

35 Council of Europe and UNESCO, "Lisbon Recognition Convention 1997."

${ }^{36}$ A constantly updated overview of signatures and ratifications may be found at https:// www.coe.int/en/web/conventions/full-list/-/conventions/treaty/165/signatures, accessed on April 8, 2019.

${ }^{37}$ Council of Europe and UNESCO, "Monitoring the Implementation of the Lisbon Recognition Convention Strasbourg" (Council of Europe Higher Education Series No. 23, Council of Europe Publishing, 2019). 
- is not. ${ }^{38}$ Recognition is an area of great public concern but also one in which institutions and national authorities show some reluctance. While all would like their own qualifications to be broadly recognized, the will to recognize the qualifications of others is somewhat less pronounced. This is particularly true for regulated professions, where most countries as well as the EU have specific legislation, but also academic recognition and recognition for unregulated professions show a measure of protectionism.

In 2012, the European Commission brought the concept of "automatic recognition" into the discussion at the very last minute, and it found its way into the communiqué ${ }^{39}$ Since then, further work has been done to make the concept a reality. What is called "automatic recognition" is a natural development within the EHEA in that it assumes that no further questions need be asked for three of the five elements making up a qualification: ${ }^{40}$ quality, level, and workload. If a given qualification is a first degree from a recognized institution that has successfully undergone quality assurance according to the ESG and belongs to an education system that has selfcertified its qualifications framework against the overarching qualifications framework of the EHEA, there should be no reason to ask further questions about these three elements; the profile and learning outcomes of the qualification must nevertheless be assessed against the purpose for which recognition is sought. My quarrel with automatic recognition is therefore not the reality but the fact that the term promises more than it can deliver.

\section{III.3. Qualifications frameworks}

Qualifications frameworks were not well known in Europe at the time when the Bologna Process was launched, and Australia, New Zealand, and South Africa were the pioneers in this area. Australia and New Zealand developed qualifications frameworks in part to make it easier for foreign students to obtain recognition of their qualifications when they returned home, since they would then have a good description of the function and place of their specific qualifications within the education system of the country in which they

${ }^{38}$ Indications are, however, that implementation of his Article has improved since the survey was conducted in late 2015/early 2016. An updated overview of the implementation of Article VII will be presented to the Lisbon Recognition Convention Committee at its meeting on June 28, 2019.

39 Bologna Process, "Bucharest Communiqué."

${ }^{40}$ Sjur Bergan, Qualifications: Introduction to a Concept, Council of Europe Higher Education Series No. 6 (Strasbourg, Council of Europe Publishing, 2007), 69-142. 
had obtained the qualification. In the case of South Africa, the qualifications framework was rather seen as an instrument that would make it easier to assess, describe, and recognize the real qualifications of many who had been denied adequate access to formal education under apartheid.

Like the ESG, work on an overarching qualifications framework for the EHEA was launched in 2003, and the framework - known as the QF-EHEA ${ }^{41}$ - was adopted in $2005 .{ }^{42}$ It took the commitment in the Bologna Declaration ${ }^{43}$ to a two cycle system a step further, both by confirming the inclusion of doctoral qualifications ${ }^{44}$ and by placing individual qualifications in context. National qualifications frameworks describe how qualifications in that system articulate and how learners can move between qualifications within the system. The QF-EHEA does the same for qualifications belonging to different systems within the EHEA. Qualifications frameworks facilitate recognition, and they incorporate the results of quality assurance. They are therefore a significant development in making the European Higher Education Area just that - a coherent higher education area rather than merely a framework of cooperation between individual national systems.

As could perhaps be expected, implementation is less good than what would have been required to have a seamless higher education area. At the latest count, 32 systems ${ }^{45}$ have completed their self-certification and therefore have fully completed national qualifications frameworks, 8 systems were reasonably close to completing them, while 8 systems were still in the early to middle stages of developing their national frameworks. ${ }^{46}$

\section{III.4. Challenges}

The fact that the reform of education system and structures has been at the heart of the EHEA since its inception does not mean all commitments have been implemented. Successive stocktaking and implementation reports show that much work is still required and that some countries are still quite

${ }^{41}$ http://www.ehea.info/media.ehea.info/file/WG_Frameworks_qualification/85/2/ Framework_qualificationsforEHEA-May2005_587852.pdf, accessed on April 8, 2019.

42 Bologna Process, "Bergen Communiqué."

${ }^{43}$ Bologna Process, "Bologna Declaration."

${ }_{44}$ Bologna Process, "Berlin Communiqué."

45 The reference is to systems rather than countries because some countries, e.g. Belgium and the United Kingdom, have more than one education system.

${ }^{46}$ European Commission/EACEA/Eurydice, "Bologna Process Implementation Report," 120. 
far from implementing one or more key commitments. The challenges in structural reforms lie more in implementation than in developing new structures and perhaps even developing new policies.

One significant development is the increasing number of qualifications that are not part of any national education system, including but not limited to qualifications from online provision. Since they do not belong to any national system within the EHEA they also do not belong to the EHEA, but the EHEA has yet to develop a common approach to them. Much of the skepticism to such qualifications may be well founded, but there is little in terms of quality assurance that may allow recognition authorities to distinguish viable non-national qualifications from less serious ones. The lack of a coherent approach may ultimately mean that some non-national qualifications may be recognized in some EHEA members but not in others, and/or that recognition in some EHEA members may be used to obtain recognition in other EHEA member states that would not recognize the qualification if the application were made directly but that may do so if the application is for recognition of a qualification that has been recognized in another EHEA member. There are real issues with non-national qualifications, and the EHEA needs to develop a coherent policy rather than brush the issue aside for formal reasons.

Mostly, however, the challenges of structural reform are of implementation rather than overall EHEA structures and policies, and it is telling that the three peer learning groups set up in the 2018-20 work program focus on recognition, qualifications frameworks, and quality assurance. These peer groups arise from the very vivid discussion on implementation and nonimplementation in the 2015-18 period, and they take us straight to the question of the character of the EHEA.

\section{The character of the EHEA}

Broadly, two very different views of the character of the EHEA may be outlined. The first sees the EHEA as a framework for voluntary cooperation and peer learning. ${ }^{47}$ The second also emphasizes these aspects but goes one step further: it underlines that once commitments have been undertaken, implementation is not optional, and that implementation will ultimately decide whether other parts of the world trust the EHEA and European higher

${ }^{47}$ Harmsen, "Future Scenarios for the European Higher Education Area: Exploring the Possibilities of "Experimentalist Governance." 
education. ${ }^{48,49}$ At their 2015 meeting, Ministers recognized that "Implementing agreed structural reforms is a prerequisite for the consolidation of the EHEA and, in the long run, for its success" and stated that "Non-implementation in some countries undermines the functioning and credibility of the whole EHEA". ${ }^{50}$

These two visions clashed quite acrimoniously within the BFUG between 2015 and 2018 in the discussion about measures to address nonimplementation. In my close to two decades in the BFUG I have seen quite strong disagreement on several issues, but I have never witnessed a similar level of acrimony. There was a fundamental disagreement over what the EHEA being a voluntary process actually meant. Albania, France and Italy led the group of BFUG members - mostly country representatives - that argued against devising specific follow up measures for countries facing problems in implementing their commitments and also argued against the use of the term "non-implementation". Iceland (as co-chair of the Advisory Group dealing with Non-Implementation ${ }^{51}$ ), Norway, Germany, the European Commission, and the Council of Europe were among those who argued that implementation of commitments undertaken should be monitored and measures taken to address serious cases of non-implementation.

Predictably, the outcome was a compromise: peer learning groups coordinating and overseen by the Bologna Implementation Coordination Group (BICG). ${ }^{52}$ The term "non-implementation" was avoided, and peer support was chosen as the preferred method of promoting implementation. At the same time, the BICG, with a majority of country representatives but also with the European Commission and stakeholder representatives as members, was established with a mandate to oversee the peer groups. Reporting on progress to the BFUG would be through the BICG rather than directly by the three peer groups. The compromise was possible in part thanks to the sustained efforts by Bulgaria and Serbia, which co-chaired the BFUG in the crucial semester leading up to the Ministerial conference. The Bulgarian Co-Chair, Ivana Radonova, played a particularly important role.

${ }^{48}$ Bergan, "The EHEA at the Cross-roads. The Bologna Process and the Future of Higher Education," 737-752.

${ }^{49}$ Una Strand Viđarsdóttir, "Implementation of Key Commitments and the Future of the Bologna Process," in European Higher Education Area: the Impact of Past and Future Policies, edited by Curaj et al. (Heidelberg/Bucureşti: Springer Open/UEFISCDI, 2018), 373-385.

${ }^{50}$ Bologna Process, "Yerevan Communiqué."

${ }^{51}$ See http://ehea.info/cid105406/ag-non-implementation-2015-2018.html, accessed on April 8, 2019.

${ }^{52}$ See http://ehea.info/page-Bologna-Implementation-Coordination-Group, accessed on April 8, 2019. 
The compromise, however, does not entirely resolve the question of what it means that the EHEA is a voluntary process. Much will depend on the work of the BICG and how this is perceived by both those who would have liked to see no BICG at all and those who would have preferred a more determined follow up of commitments undertaken but not honored. Much will also depend on the reaction of those outside the BFUG and even of the EHEA. Will a European Higher Education Area relying largely on "peer learning +" be seen as a coherent area the value of whose qualifications can be trusted? If, as we must hope, the answer is positive, we will have identified a good way of fostering implementation, even if the process of getting here was painful. If the answer is negative, the debate on implementation may have to be reopened in the course of the next decade of the EHEA.

A particular case was that of Belarus, which - as noted above - acceded to the EHEA accompanied by a Roadmap ${ }^{53}$ that outlined reforms the country was to undertake by 2018 and the implementation of which was overseen by an Advisory Group in which Belarus participated but in a minority position. The link to the broader discussion was underscored by the membership of the group, which included Germany and the Holy See (co-chairs), France, Iceland as co-chair of the Working Group on Non-Implementation, the European Commission, and the Council of Europe. Because of the sensitivity of the discussion, this was the only working or advisory group whose documents were not publicly available through the EHEA web site. Belarus was in the end far from implementing many of its commitments ${ }^{54}$ but at the same time argued strongly the Roadmap should not be prolonged. Here also, the solution chosen was a compromise: the Roadmap was replaced by a strategic plan devised by Belarus but commented on by BFUG members. The implementation would be overseen by Belarus but it committed to doing so by involving foreign experts, and it would report back to the Bologna Board.

\section{Fundamental values and the purposes of higher education}

Another area in which there is considerable diversity between EHEA members is the fundamental values on which the EHEA builds: academic freedom, institutional autonomy, and student and staff participation in higher

${ }^{53}$ Bologna Process, "Belarus Roadmap for Higher Education Reform," accessed April 8, 2019. http://www.ehea.info/media.ehea.info/file/2015_Yerevan/70/9/Roadmap_ Belarus_21.05.2015_613709.pdf.

${ }^{54}$ This was the unanimous view of the non-Belarusian members of the Advisory Group, but the view was not shared by the representatives of Belarus. 
education governance. Commitment to those values has been a requirement for EHEA membership at least since 2004, ${ }^{55}$ and the commitment was long taken for granted even if there was recognition that the commitment was less than perfect in some members.

The situation changed with the 2015-18 work program, and the fundamental values became an area of concern, as underscored by the thematic debate held in Bratislava in December 2016 supported by a discussion document co-authored by the Council of Europe, the Magna Charta Observatory, the International Association of Universities, and the (then) French Vice Chair of the BFUG. ${ }^{56}$ The renewed concern was brought about by at least three developments: the accession of Belarus, whose application had been turned down in $2012^{57}$ because of arrests of members of the academic community protesting the Presidential election in December 2010; developments in Turkey, where many members of the academic community (as well as of the media and the judiciary) were arrested or subjected to travel and other restrictions in the aftermath of the failed coup in July 2016; and the situation of the Central European University (CEU), whose already tenuous position in Hungary was made even more difficult after Parliament, spurred by the government, adopted legislative changes that finally obliged the CEU to move its teaching to Wien as of fall 2019.

The renewed focus on fundamental values underlines the link between the EHEA and the broader foreign policy agenda of many member states as well as the European Commission. Education can be used as a "soft diplomacy" tool to develop people-to-people exchanges ${ }^{58}$ and contacts that can then help political cooperation. At the same time, education builds on values that cannot just be set aside. The EHEA would not be European without its fundamental values.

This points to an even more overlooked issue: the purposes of higher education. That higher education plays and should play a major role in

55 Bologna Process 2004, "Further Accession to the Bologna Process. Procedures for Evaluation of Applications and Reports from Potential New Members" (Document BFUG B3 7 dated October 4, 2004), accessed April 8, 2019, http://www.ehea.info/media.ehea.info/ file/20041012-13_Noordwijk/79/9/BFUG3_7_further_accessions_579799.pdf.

${ }_{56}$ Bologna Process 2016, "Academic freedom and institutional autonomy - what role for the EHEA?" (Background document for the thematic session of the Bologna Follow Up Group, Bratislava, December 8 - 9, 2016, written by Sjur Bergan, Eva Egron-Polak, Sijbolt Noorda, and Patricia Pol), accessed April 8, 2019, http://ehea.info/media.ehea.info/file/20161208-09Bratislava/12/8/BFUG_SK_ME_52_9_Fundamental_values_669128.pdf.

${ }^{57}$ Bologna Process, "Meeting of the Bologna Follow-Up Group" (Draft outcome of proceedings,_Document BFUG_DK_AZ_29_3b, Copenhagen, January 18-19, 2012).

58 This is the term used by ASEF, the Asia-Europe Foundation. 
preparing for the labor market and in developing the economy is undisputed. However, this is not the only purpose of education. The Council of Europe has defined four major purposes:

- Preparation for the labor market

- Preparation for life as active citizens in democratic societies

- Personal development

- The development and maintenance of a broad and advanced knowledge base..$^{59,60}$

The contention that higher education has several purposes is perhaps not hugely controversial but it has also not been very operational within the EHEA, and discussions have often ended with an affirmation that while all purposes are important, the economic purpose of higher education must be given priority.

However, references to the multiple purposes of higher education started being reflected in Ministerial communiqués as of $2007,{ }^{61}$ and the Yerevan Communiqué ${ }^{62}$ emphasized the societal and democratic role of higher education much more strongly than previously. In the Yerevan Communiqué, Ministers underlined: "We will support and protect students and staff in exercising their right to academic freedom and ensure their representation as full partners in the governance of autonomous higher education institutions. We will support higher education institutions in enhancing their efforts to promote intercultural understanding, critical thinking, political and religious tolerance, gender equality, and democratic and civic values, in order to strengthen European and global citizenship and lay the foundations for inclusive societies." They also included "making our systems more inclusive" as one of their main priorities.

Nevertheless, even if there is now greater focus on the fundamental values of higher education as well as greater awareness of its societal and not only economic role, the democratic mission of higher education is not strongly reflected in the structural reforms of the EHEA. This may be partly because the QF-EHEA and the ESG were developed at a time when there

${ }^{59}$ Sjur Bergan, "Higher Education as a 'Public Good and a Public Responsibility': What Does it Mean?", in The Public Responsibility for Higher Education and Research, edited by Luc Weber and Sjur Bergan (Strasbourg: Council of Europe Publishing Council of Europe Higher Education Series No. 2, 2005), 13-28.

${ }^{60}$ Council of Europe, "Recommendation Rec/CM(2007)6 by the Committee of Ministers to member states on the public responsibility for higher education and research."

${ }^{61}$ Bologna Process, "London Communiqué."

62 Bologna Process, "Yerevan Communiqué." 
was less focus on the broader purposes of higher education and partly because the economic role of higher education tends to carry the day in national policies. Making the democratic mission of higher education key to the EHEA is one of the challenges we should rise to in the next decade of the EHEA. That challenge has not been made easier or less important by the rise of populism in any countries, to the extent that it constitutes or influences the programs of many governments in the EHEA.

One area, however, has been important at least since the Prague conference. ${ }^{63}$ Student and staff participation in higher education governance is a characteristic of European higher education and one of the elements that distinguish us from most other areas of the world. The Council of Europe has a long-standing cooperation with US partners in the International Consortium for Higher Education, Civic Responsibility, and Democracy.$^{64}$ While US institutions demonstrate a stronger awareness of their role as democratic actors in broader societies, not least in their local communities, student and staff influence on institutional policy as well as on the development of national education systems and policies is much stronger in Europe.

\section{The EHEA in a global context}

That European higher education works within a global context is a truism but that does not mean the EHEA has found a format of cooperation with the rest of the world. This is true even if other areas, in particular Asia, ${ }^{65,66}$ have looked to the EHEA for inspiration. The Bologna Policy Forum (BPF) was devised as a means to implement the EHEA Global Dimension Strategy..$^{67,68}$

${ }^{63}$ Bologna Process, "Prague Communiqué."

${ }^{64} \mathrm{https} / / / \mathrm{www}$.internationalconsortium.org/, accessed April 8, 2019.

${ }^{65}$ QueAnh Dang, "The Bologna Process Goes East? from 'Third Countries' to Prioritizing Inter-regional Cooperation Between the ASEAN and EU," in The European Higher Education Area: Between Critical Reflections and Future Policies, ed. Adrian Curaj, Liviu Matei, Remus Pricopie, Jamil Salmi and Peter Scott (Heidelberg: Springer Open Access, 2015), 763 - 783.

${ }^{66}$ QueAnh Dang, "Unintended Outcomes of the EHEA and ASEAN: Peripheral Members and their Façade Conformity," in European Higher Education Area: the Impact of Past and Future Policies, eds. Curaj et al. (Heidelberg/Bucureşti: Springer Open/UEFISCDI, 2018), 387-406.

${ }^{67}$ Bologna Process, "European Higher Education in a Global Setting. A Strategy for the External Dimension of the Bologna Process," accessed April 8, 2019, https://media.ehea.info/ file/2007_London/35/4/2007_London_Strategy-for-EHEA-in-global-setting_581354.pdf

${ }^{68}$ Pavel Zgaga, "Looking out: The Bologna Process in a Global Setting. On the 'External Dimension' of the Bologna Process" (Oslo: Norwegian Ministry of Education and Research, 
The first BPF was held in 2009, and it has been held as part of or in conjunction with every Ministerial conference since then.

It would be difficult to argue that the BPF has been an unmitigated success or that it has found its form. The basic issue may be trying to square the circle. It is difficult for Ministers to meet for more than a day and a half, and EHEA Ministers need to conduct EHEA business as well as interact with their peers from other regions. This has led to series of unsatisfactory formulas that did not leave sufficient time for either the EHEA Ministerial conference of the BPF.

Another issue is the preparation of the BPF. There is no process of joint preparation and no series of topical discussions bringing together highranking civil servants and institutional leaders from the EHEA and other regions. Making the BPF - or another framework with similar objectives - an area for meaningful debate and cooperation on a global scale will be another challenge for the next decade of the EHEA.

\section{Governance and relevance}

The EHEA is an intergovernmental process but higher education policy cannot be developed and implemented in Ministry offices alone. Representatives of institutions, students, and staff therefore have an important role in the EHEA and their influence in the BFUG is stronger than their numbers and their status as consultative members would imply.

The fact that the BFUG is a venue where representatives of ministries, stakeholders, and international institutions and organizations debate and make decisions together, and that they work together in the various groups of the work program, is one of the strengths of the EHEA. Other aspects of the BFUG are less comforting, in particular the relative silence of many member states in discussions and the relatively weak contacts many BFUG representatives have with the political decision makers in their ministries.

Even if the EHEA is a loose process, it requires a measure of organization. As we have seen, it is overseen by the BFUG and Board between Ministerial conferences, and the BFUG adopts a fairly detailed work program soon after each Ministerial conference, based on the priorities in the communique that Ministers have adopted. Since 2009, the BFUG has been co-chaired by the

2007), accessed April 8, 2019,www.ehea.info/media.ehea.info/file/WG_External_ dimension/34/3/ExternalDimension_report2007_581343.pdf. 
country holding the EU presidency and a non-EU country. ${ }^{69}$ Until then, the BFUG had been chaired by the country holding the EU Presidency. A first attempt to give non-EU countries a stronger and more visible role was an extraordinary meeting held in Sarajevo in 2008, at the initiative of the Slovenian EU presidency and Bosnia and Herzegovina, to host the first thematic discussion within the BFUG on the future of the EHEA.$^{70}$ The work program relies on classical intergovernmental instruments like working groups and reports, and the energy spent on deciding whether a given group should be labeled a "working", "advisory", or "coordination" groups, and on whether any given group should have sub-group, does not bear witness to a lack of bureaucracy.

In the early years, the EU presidency country also provided the secretariat of the BFUG. Since 2003, however, the country hosting the forthcoming Ministerial conference also provides the BFUG Secretariat. The Secretariat is set up in the upcoming host country-normally within or at least under the authority of its Ministry responsible for higher education, and it operates under the legislation of this country. With the exception of the 2007-2010 Secretariat, which was provided by Belgium (both communities), Luxembourg, and the Netherlands, as they all hosted the 2009 Leuven/ Louvain-la-Neuve Ministerial conference together, ${ }^{71}$ all BFUG Secretariats have been national. Since the current Secretariat arrangement was established, it was intended that other EHEA members could second officials to the Secretariat, but this has only happened since 2015 , and on a limited scale.

There is considerable dissatisfaction within the BFUG with the current Secretariat arrangement, as it provides no continuity beyond any given work period. The quality of the Secretariats has also been somewhat diverse, with the initial Norwegian and above all the Romanian Secretariats as the most successful. Therefore, the question of what has been labeled a "permanent" BFUG Secretariat has been raised from time to time.

${ }^{69}$ Bologna Process, "The Bologna Process 2020 - The European Higher Education Area in the new decade" (Communiqué of the Conference of European Ministers Responsible for Higher Education, Leuven and Louvain-la-Neuve, April 28 - 29, 2009), accessed April 8, 2019, http://www.ehea.info/Upload/document/ministerial_declarations/Leuven_Louvain_la_ Neuve_Communique_April_2009_595061.pdf.

${ }^{70}$ Bologna Process, "Bologna 2020" (Discussion document issued to the Bologna Follow Up Group for its extraordinary meeting in Sarajevo, issue date June 12, 2008), accessed April 8, 2019, https://media.ehea.info/file/20080624-25-Sarajevo/01/1/BFUG_Sarajevo_ Bologna2020paper_593011.pdf.

${ }^{71}$ Since the 2010 Ministerial conference, held in Budapest and Wien and co-hosted by Hungary and Austria, was held only one year later, the same Secretariat continued to serve the BFUG, reinforced by one member from each of the two new host countries. 
Such a Secretariat would provide greater stability and would be more independent from any given national Ministry. This is an important point, since many of the Secretariats since 2013 have taken instructions as much from their national authorities as from the BFUG. There is therefore a clear case for a Secretariat that works with a time horizon that is not limited to a single work program or Ministerial conference. To establish such a Secretariat, however, a good number of issues would need to be resolved, ${ }^{72,73}$ including financial arrangements and guarantees for the Secretariat, the authority under which the Secretariat would work, arrangements for hiring and - in the worst of cases - firing staff, and arrangements for pensions and social security, and the seat and legal arrangements for the Secretariat. Even if these challenges have so far kept the BFUG from exploring a "permanent" Secretariat further, the BFUG will most likely need to explore this option in greater detail as the EHEA enters its third decade.

The level of national representation is an indication of whether the EHEA and the BFUG are perceived as politically relevant. They clearly were in the first couple of phases of the development of the EHEA but political level representation at Ministerial conferences has gone down over time. ${ }^{74}$ The 2018 Paris conference represented a clear reversal of the trend, as 42 of the 48 member states were represented at political level ${ }^{75}$ but it remains to be seen whether the reversal will be more permanent.

At least since the preparation of the 2007 Ministerial conference the EHEA has been torn between focusing on implementing the goals that have already been adopted and developing new goals. There are clear arguments for focusing on implementation, as successive stocktaking and implementation reports have shown that implementation is imperfect for most goals and dramatically so in some cases. At the same time, however, it is difficult to maintain political commitment to a process that focuses only on implementation.

While structural reforms have been and are likely to remain at the heart of the EHEA, the EHEA cannot be reduced to structural reforms alone. In addition to the renewed attention to fundamental values and the global

72 Bergan, "The EHEA at the Cross-roads. The Bologna Process and the Future of Higher Education," 737-752.

${ }^{73}$ Bergan and Deca, "Twenty Years of Bologna and a Decade of EHEA: What is Next?," 283-306.

${ }^{74}$ Ibid., $286-287$.

${ }^{75}$ Françoise Profit, "The Paris Ministerial Conference", presentation to the Bologna Follow Up Group (Wien, September 27, 2018), 3, accessed April 8, 2019, http://www ehea. info/Upload/BFUG_AU_CH_63_4c_Ministerial_Conference.pdf. 
dimension of higher education described above, topics the BFUG has worked or is working on include the social dimension of higher education, mobility teaching and learning, the impact of digitalization, or student support. It is nevertheless symptomatic that the Advisory Group on New Goals, whose task was precisely to suggest new priorities for the EHEA, was, in my view, the least successful Working or Advisory Group in the 2015-18 program.

A consideration of future priorities for the EHEA cannot be divorced from a consideration of what policy areas lend themselves to a loose framework of 48 countries with a high degree of diversity. There is little doubt that the financing of higher education is a priority for most if not all Ministries of EHEA countries. It is far less obvious that the EHEA lends itself to joint action on financing, as the economic realities and policies of EHEA members are probably too diverse.

\section{Conclusion}

The development of the EHEA has been a mix of success and failure. ${ }^{76}$ In spite of its imperfections, I would nevertheless argue that the EHEA has been a remarkable success and that it has changed higher education in Europe. The EHEA rapidly became a framework that no European country felt it could afford to ignore, and 48 countries now cooperate on higher education reforms in ways that the signers of the Bologna Declaration in 1999 could probably not have imagined. Only two countries party to the European Cultural Convention - San Marino and Monaco - are currently not EHEA members, and San Marino has recently indicated renewed interest.

At the same time, the EHEA is unsure about its future, for reasons described in this article. To be a success, the EHEA needs to define its character and identity. I am among those who believe this identity should include an element of peer pressure somewhat stronger than the current emphasis on peer learning even if it is unlikely to extend to formal monitoring and even less to raise questions of suspension and exclusion, which was also never at the heart of the discussion of non-implementation.

But focusing on implementation alone will not be enough. As it approaches its third decade, the EHEA may be shaken but there is little indication it is sufficiently stirred. If we are to be able to conduct a similar

${ }^{76}$ Eva Maria Vögtle, "20 years of Bologna - a story of success, a story of failure," Innovation: The European Journal of Social Sciences Research, https://doi.org/10.1080/13511 610.2019.1594717, accessed April 8, 2019. 
discussion of its fourth decade as we approach 2030, the EHEA of today must find a stronger sense of purpose for tomorrow. These must, in my view, reconcile the structures that have been the EHEA's greatest success with what should be the EHEA's greatest promise: the role of higher education in helping European societies rise to the greatest challenges they face: the threats to our environmental, societal, cultural, political, and economic sustainability. A European Higher Education Area that serves as the framework for developing European policies to protect our physical environment, overcome populism, and develop the kind of societies in which we would like to live has a future. That future depends on our ability to develop the kind of transversal competences that higher education should develop in all its students and that are included in the Council of Europe's Reference Framework of Competences for Democratic Culture. ${ }^{77}$

In Bucureşti, where the BFUG met in early April 2019, many banners celebrate the Romanian EU Presidency. One of them hangs on a building that now houses the Ministry of the Interior, but this building has a history. In Ceauşescu's time this building housed the Communist Party Central Committee, and it has a balcony from which the dictator delivers some of his speeches to the "toiling masses", including his last one. At the time of writing, a banner celebrating the EU Presidency hangs just above this balcony.

It would be difficult to find a better illustration of how far Europe has come since 1989, in spite of all our challenges. The EHEA would not have been possible had these political changes not taken place. But the success of our societies also depends in part on our having higher education that will not only train subject specialists but educate intellectuals who have the will and ability to place their own academic discipline in a broader context, ask critical questions but also find the answers to those questions. An EHEA that fosters this kind of higher education will not find itself where Ceauşescu deservedly ended up: on the scrap heap of history.

\section{Bibliography}

Bergan, Sjur. "Higher Education as a "Public Good and a Public Responsibility": What Does it Mean?" In The Public Responsibility for Higher Education and

77 Council of Europe, "Reference Framework of Competences for Democratic Culture". Accessed April 8, 2019. https://www.coe.int/en/web/education/competences-for-democratic-culture. 
Research, edited by Luc Weber and Sjur Bergan, 13-28. Strasbourg: Council of Europe Publishing Council of Europe Higher Education Series No. 2, 2005.

- Qualifications: Introduction to a Concept. Council of Europe Higher Education Series No. 6. Strasbourg: Council of Europe Publishing, 2007.

. "The EHEA at the Cross-roads. The Bologna Process and the Future of Higher Education." In The European Higher Education Area: Between Critical Reflections and Future Policies, edited by Adrian Curaj, Liviu Matei, Remus Pricopie, Jamil Salmi and Peter Scott, 737-752. Heidelberg: Springer Open Access, 2015.

Bergan, Sjur, and Ligia Deca. "Twenty Years of Bologna and a Decade of EHEA:

What is Next?" In European Higher Education Area: the Impact of Past and Future Policies, edited by Curaj et al., 283-306. Heidelberg/Bucureşti: Springer Open/UEFISCDI , 2018. Accessed April 8, 2019. https://link.springer.com/ chapter/10.1007/978-3-319-77407-7_19.

Bologna Process. "Sorbonne Joint Declaration." Joint declaration on harmonisation of the architecture of the European higher education system by the four Ministers in charge for France, Germany, Italy and the United Kingdom, Paris: Sorbonne, May 25, 1998. Accessed April 8, 2019. http://www.ehea.info/ media.ehea.info/file/1998_Sorbonne/61/2/1998_Sorbonne_Declaration_ English_552612.pdf,

. "The Bologna Declaration of 19 June 1999." Joint declaration of the European Ministers of Education. Accessed April 8, 2019. http://www.ehea. info/Upload/document/ministerial_declarations/1999_Bologna_Declaration_ English_553028.pdf.

- "Towards the European Higher Education Area." Communiqué of the meeting of European Ministers in charge of Higher Education, Prague, May 19, 2001. Accessed April 8, 2019. http://www.ehea.info/Upload/document/ ministerial_declarations/2001_Prague_Communique_English_553 442.pdf.

_. "Realising the European Higher Education Area." Communiqué of the Conference of Ministers responsible for Higher Education, Berlin, September 19, 2003. Accessed April 8, 2019. http://www.ehea.info/Upload/document/ ministerial_declarations/2003_Berlin_Communique_English_577284.pdf.

- "Further Accession to the Bologna Process. Procedures for Evaluation of Applications and Reports from Potential New Members." Document BFUG B3 7, dated October 4, 2004. Accessed April 8, 2019. http://www .ehea.info/media. ehea.info/file/20041012-13_Noordwijk/79/9/BFUG3_7_further_ accessions_579799.pdf.

— "The European Higher Education Area-Achieving the Goals." Communiqué of the Conference of European Ministers Responsible for Higher Education, Bergen, May 19-20, 2005. Accessed April 8, 2019. http://www.ehea.info/ Upload/document/ministerial_declarations/2005_Bergen_Communique_ english_580520.pdf.

. "Meeting of the Bologna Follow-Up group, Helsinki, Finland, 12-13 October 2006.” Document BFUG10 3a. Accessed April 8, 2019. https://media. 
ehea.info/file/20061012-13_Helsinki/04/5/BFUG9_Minutes_Helsinki_ October2006_585045.pdf.

. "London Communiqué. Towards the European Higher Education Area: responding to challenges in a globalised world." Communiqué of the Conference of European Ministers Responsible for Higher Education, London, May 18, 2007. Accessed April 8, 2019. http://www.ehea.info/Upload/document/ ministerial_declarations/2007_London_Communique_English_588697.pdf.

_ . "European Higher Education in a Global Setting. A Strategy for the External Dimension of the Bologna Process.” Accessed April 8, 2019. https://media.ehea. info/file/2007_London/35/4/2007_London_Strategy-for-EHEA-in-globalsetting_581354.pdf.

—. "Bologna 2020". Discussion document issued to the Bologna Follow Up Group for its extraordinary meeting in Sarajevo, issue date June 12, 2008. Accessed April 8, 2019.https://media.ehea.info/file/20080624-25-Sarajevo/01/1/ BFUG_Sarajevo_Bologna2020paper_593011.pdf.

—. "The Bologna Process 2020 - The European Higher Education Area in the new decade." Communiqué of the Conference of European Ministers Responsible for Higher Education, Leuven and Louvain-la-Neuve, April 28-29, 2009. Accessed April 8, 2019. http://www.ehea.info/Upload/document/ministerial_ declarations/Leuven_Louvain_la_Neuve_Communique_April_2009_595061. pdf.

- "Making the Most of Our Potential: Consolidating the European Higher Education Area. Bucharest Communiqué." Communiqué of the Conference of European Ministers Responsible for Higher Education, Bucharest, April 26-27, 2012. Accessed April 8, 2019. http://www.ehea.info/Upload/document/ ministerial_declarations/Bucharest_Communique_2012_610673.pdf.

- "Meeting of the Bologna Follow-Up Group" (Draft outcome of proceedings, Document BFUG_DK_AZ_29_3b,Copenhagen, January 18-19, 2012).

- "Report by the Structural Reforms Working Group to the BFUG." Accessed April 8, 2019. http://bologna-yerevan2015.ehea.info/files/Final\%20Report\%20 of\%20the\%20Structural\%20Reforms\%20WG.pdf.

- "Yerevan Communiqué." Communiqué of the Conference of European Ministers Responsible for Higher Education, Yerevan, May 14-15, 2015. Accessed April 8, 2019. http://www.ehea.info/media.ehea.info/file/2015_ Yerevan/70/7/YerevanCommuniqueFinal_613707.pdf.

. "Belarus Roadmap for Higher Education Reform.”. Accessed April 8, 2019. http://www.ehea.info/media.ehea.info/file/2015_Yerevan/70/9/Roadmap_ Belarus_21.05.2015_613709.pdf.

—. "Standards and Guidelines for Quality Assurance in the European Higher Education Area." Revised version. Accessed April 8, 2019. http://www.ehea. info/media.ehea.info/file/2015_Yerevan/72/7/European_Standards_and_ Guidelines_for_Quality_Assurance_in_the_EHEA_2015_MC_613727.pdf.

. "Academic freedom and institutional autonomy - what role for the EHEA?" Background document for the thematic session of the Bologna Follow Up 
Group, Bratislava, December 8-9, 2016, written by Sjur Bergan, Eva EgronPolak, Sijbolt Noorda, and Patricia Pol. Accessed April 8, 2019. http://ehea.info/ media.ehea.info/file/20161208-09-Bratislava/12/8/BFUG_SK_ME_52_9_ Fundamental_values_669128.pdf.

. "Paris Communiqué." Communiqué of the Conference of European Ministers Responsible for Higher Education, Paris, May 24-25, 2018. Accessed April 8, 2019. http://www.ehea.info/Upload/document/ministerial_declarations/ EHEAParis2018_Communique_final_952771.pdf.

Council of Europe. "Recommendation Rec/CM(2007)6 by the Committee of Ministers to member states on the public responsibility for higher education and research." Accessed April 8, 2019. https://search.coe.int/cm/Pages/result_ details .aspx? ObjectId=09000016805d5dae.

_. "Reference Framework of Competences for Democratic Culture.” Accessed April 8, 2019. https://www.coe.int/en/web/education/competences-fordemocratic-culture.

Council of Europe and UNESCO. "Convention on the Recognition of Qualifications concerning Higher Education in the European Region.” Lisbon Recognition Convention, 1997. Accessed April 16, 2019. https://www.coe.int/en/web/ conventions/full-list/-/conventions/treaty/165 .

_. "Monitoring the Implementation of the Lisbon Recognition Convention Strasbourg." Council of Europe Higher Education Series No. 23. Council of Europe Publishing, 2019.

Dang, QueAnh. "The Bologna Process Goes East? from 'Third Countries' to Prioritizing Inter-regional Cooperation Between the ASEAN and EU." In The European Higher Education Area: Between Critical Reflections and Future Policies, edited by Adrian Curaj, Liviu Matei, Remus Pricopie, Jamil Salmi and Peter Scott, 763-783. Heidelberg: Springer Open Access, 2015.

_. "Unintended Outcomes of the EHEA and ASEAN: Peripheral Members and their Façade Conformity." In European Higher Education Area: the Impact of Past and Future Policies, edited by Curaj et al., 387-406. Heidelberg/Bucureşti: Springer Open/UEFISCDI, 2018.

European Commission/EACEA/Eurydice. "The European Higher Education Area in 2018: Bologna Process Implementation Report.” Luxembourg: Publications Office of the European Union, 2018. Accessed April 8, 2019. http://www.ehea. info/Upload/BP2018.pdf.

Harmsen, Robert. "Future Scenarios for the European Higher Education Area: Exploring the Possibilities of "Experimentalist Governance." In The European Higher Education Area: Between Critical Reflections and Future Policies, edited by Adrian Curaj, Liviu Matei, Remus Pricopie, Jamil Salmi and Peter Scott, 785-803. Heidelberg: Springer Open Access, 2015.

Profit, Françoise. "The Paris Ministerial Conference." Presentation to the Bologna Follow Up Group, Wien, September 27, 2018. Accessed April 8, 2019. http:// www.ehea.info/Upload/BFUG_AU_CH_63_4c_Ministerial_Conference.pdf. 
Strand Viđarsdóttir, Una. "Implementation of Key Commitments and the Future of the Bologna Process." In European Higher Education Area: the Impact of Past and Future Policies, edited by Curaj et al., 373-385. Heidelberg/Bucureşti: Springer Open/UEFISCDI, 2018.

Vögtle, Eva Maria. "20 years of Bologna - a story of success, a story of failure." Innovation: The European Journal of Social Sciences Research. https://oi.org/ 10.1080/13511610.2019.1594717. Accessed April 8, 2019.

Zgaga, Pavel. "Looking out: The Bologna Process in a Global Setting. On the 'External Dimension' of the Bologna Process." Oslo: Norwegian Ministry of Education and Research, 2007. Accessed April 8, 2019. www.ehea.info/media. ehea.info/file/WG_External_dimension/34/3/ExternalDimension_ report2007_581343.pdf.

\section{About the author}

SJUR BERGAN (sjur.bergan@coe.int) is Head of the Education Department of the Council of Europe and leads the current Council of Europe projects on Competences for Democratic Culture and the European Qualifications Passport for Refugees. He has represented the Council of Europe in the Bologna Follow Up Group and Board since 2000 and chaired three successive working groups on structural reforms 2007 - 15. Sjur was a member of the editorial group for the Council's White Paper on Intercultural Dialogue and a main author of the Lisbon Recognition Convention as well as of recommendations on the public responsibility for higher education; academic freedom and institutional autonomy; and ensuring quality education. Sjur Bergan is series editor of the Council of Europe Higher Education Series and the author of Qualifications: Introduction to a Concept and Not by Bread Alone as well as of numerous book chapters and articles on education and higher education policy. Sjur was also one of the editors of the Raabe Handbook on Leadership and Governance in Higher Education (2009-15). 


\title{
The European Higher Education Area: A road to the future or at way's end?
}

\author{
Sjur Bergan
}

doi: http://dx.doi.org/10.18543/tjhe-6(2)-2019pp23-49

\section{Copyright}

Copyright for this article is retained by the Publisher. It is an Open Access material that is free for full online access, download, storage, distribution, and or reuse in any medium only for noncommercial purposes and in compliance with any applicable copyright legislation, without prior permission from the Publisher or the author(s). In any case, proper acknowledgement of the original publication source must be made and any changes to the original work must be indicated clearly and in a manner that does not suggest the author's and or Publisher's endorsement whatsoever. Any other use of its content in any medium or format, now known or developed in the future, requires prior written permission of the copyright holder. 